\title{
On a New Species of Phyllodistomum Braun, 1899 (Digenea: Gorgoderidae), A Parasite of Fresh Water Fish, Channa Punctatus (BL.) From Betwa River, Bundelkhand Region Jhansi, U.P, India
}

\author{
JAG MOHAN SEN \\ Department of Zoology, Pt. Vasudev Tiwari Girls Degree College, Jhansi, U.P, India. \\ http://dx.doi.org/10.12944/CWE.9.1.29
}

(Received: Feburary 15, 2014; Accepted: March 20, 2014)

\begin{abstract}
The present paper deals with a new species of genus Phyllodistum Braun, 1899 Phyllodistomum betwaensis sp.n. is reported from fresh water fish Channa punctatus (BI.) from Betwa river, Bundelkhand region, Jhansi. It differs from all the earlier reported species in having the body of fluke is spatulate and dorso-ventrally flattened; anterior portion of body is long and curved while posterior portion of body is broad; slightly curved, tubular oesophagus: ventral sucker oval and larger than oral sucker; testes, post-equatorial, inter-caecal, anterior testis is larger than posterior one and parallel to ovary; ovary, oval, just behind right vitelline lobe, parallel to anterior testis; vitelline lobes posterior-lateral to ventral sucker, oval. Right vitelline lobe is larger than left vitelline lobe; eggs are oval and non-operculated.
\end{abstract}

Key words: Phyllodistomum, Betwa River, Bundelkhand region and Channa punctatus.

\section{INTRODUCTION}

Fishes are important animals in ecosystem. They are useful item of human food as well as the source of income. Fishes are important for providing nourishment to poultry and cattle, and also useful for producing a high quality of manure especially for citrus plant, as a source of nitrogen and phosphate. The present study was aimed that determining the intestinal digenetic trematodes found in fishes of Betwa river of Bundelkhand region, Jhansi. This paper includes the description of a new species of Genus Phyllodistomum, 1899 found in the intestine of many specimens of Chanana punctatus (BI.).

\section{MATERIAL AND METHODS}

Fishes for the present investigation have been collected from Betwa River, Jhansi. Fishes were examined for intestinal parasites. The intestine was removed from the body cavity and contents were then examined under microscope. The parasites taken out and fixed in $70 \%$ ethanol. Specimens were stained in Aceto-alum carmine, dehydrated and mounted in Canada balsam. Diagram was made with aid of a Camera lucida device. Identification and classification of the specimen was done using Yamaguti (1958) and Overstreet and Curren (2002).

\section{Phyllodistomum betwaensis n.sp.* Description}

Body spatulate, divisible in to a narrow tubular, curved fore body and expanded hind end of the body, 1.4-1.6 mm long; 0.41-0.43 mm wide with wavy margin. Anterior part of body, narrow, elongated, curved $0.81-0.83 \mathrm{~mm}$ long $0.19-0.21 \mathrm{~mm}$ wide; posterior part of body, spatulated, 0.61-0.63 $\mathrm{mm}$ long, 0.41-0.43 mm wide. Oral sucker, terminal, slightly oval, mouth opening ventrally, no noticeable papillae on oral sucker. Oral sucker, 0.15-0.17 mm long, 0.11-0.13 mm wide.

Pharynx and pre-pharynx are absent. Mouth leads into oesophagus; oesophagus slightly 
curved, tubular, 0.09-0.11 mm long, 0.03-0.05 mm wide, and oesophagus bifurcates into two unbranched intestinal caeca which extends up to the hind end of body.

Ventral sucker, oval, 0.23-0.25 mm long, $0.17-0.19 \mathrm{~mm}$ wide. Ventral sucker is larger than oral sucker. Vitelline lobes two, posterior-lateral to ventral sucker, oval, and rarely lobed. Right vitelline lobe is larger than left vitelline lobe. Right vitelline lobe, 0.08-0.01 mm long, 0.03-0.05 mm wide. Left vitelline lobe, $0.05-0.07 \mathrm{~mm}$ long, $0.02-0.04 \mathrm{~mm}$ wide, at $0.86-0.88 \mathrm{~mm}$ from anterior extremity. The distance between the two vitelline lobes, 0.03-0.05 $\mathrm{mm}$ at greatest width.

Testes located in the broadest part of the hind body, post-equatorial, tandem, inter-caecal and deeply lobed, present between the two intestinal caeca. Anterior testis $0.13-0.15 \mathrm{~mm}$ long, 0.1-0.12 $\mathrm{mm}$ wide, at 0.09-0.092 $\mathrm{mm}$ from anterior extremity. Posterior testis, $0.11-0.13 \mathrm{~mm}$ long, 0.08-0.1 mm wide, at $1.0-1.1 \mathrm{~mm}$ from anterior extremity. Anterior testis is larger than posterior one and parallel to ovary.

Ovary oval, post-equatorial, inter-caecal, just behind of right vitelline lobe and parallel to

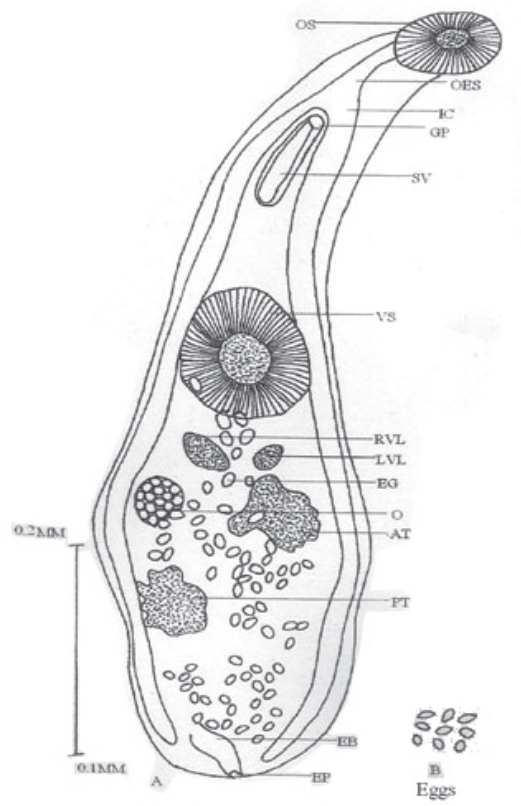

Fig. 1: Phyllodistomum between is n.sp anterior testis, $0.09-0.11 \mathrm{~mm}$ long, $0.06-0.08 \mathrm{~mm}$ wide, at $0.92-0.94 \mathrm{~mm}$ from anterior extremity. Seminal vesical, pre-acetabular, sac-like in appearance, 0.17-0.19 mm long, 0.05-0.07 mm wide. Genital pore median just blow the intestinal bifurcation. Excretory bladder, sacullar, excretory pore median. No body folds or other demarcation in hind body. Eggs, oval, non-operculated, 0.020.04 m long, 0.01-0.02 $\mathrm{mm}$ wide.

\section{DISCUSSION}

The present form resembles to $P$. triangulate $^{9}$, P. fundul ${ }^{\beta}, P$. srivastava ${ }^{\beta}, P$. vachius ${ }^{3}, P$. rhamidiae $^{11}, P$. $\operatorname{tana}^{13}, P$. laxmibai ${ }^{10}$, in having oval oral sucker. The new species differs from $P$. triangulate $^{9}$, P. fundul ${ }^{\hat{}}$, . . srivastava ${ }^{8}, P$. vachius ${ }^{3}$, P. rhamidiae ${ }^{11}$, P. $\operatorname{tana}^{13}$, P. laxmibai ${ }^{10}$, in having anterior portion of body is long and curved while posterior portion of body broad; slightly curved, tubular oesophagus; ventral sucker oval, and larger than oral sucker.

The new species resembles $P$. scrippsi ${ }^{2}, P$. singhia ${ }^{5}$, P. lysteri ${ }^{4}$, P. centopomi ${ }^{4}$, P. pavlovaskii ${ }^{12}$, $P$. laxmibailo, in having median genital pore just below the intestinal bifurcation. The new species differ from P. scrippsi ${ }^{2}, P$. singhia ${ }^{5}, P$. lysteri ${ }^{4}, P$.

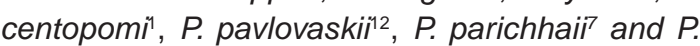
pahujii ${ }^{7}, P$. laxmibai ${ }^{10}$, in having post-equatorial, intercaecal, lobed testes. Anterior testis is larger than posterior one and parallel to ovary; position of oval, ovary just behind right vitelline lobe, parallel to anterior testis.

The new species also differ from, $P$. scripps $^{2}$, P. singhia ${ }^{5}$, P. vachius ${ }^{3}, S$ P. lyster $i^{4}, P$. centopomi ${ }^{1}$, P. pavlovaskii ${ }^{12}$, P. triangulate ${ }^{9}, P$. fundul $^{\hat{p}}$, P. srivastava ${ }^{8}$, P. rhamidiae ${ }^{11}$, P. $\tan ^{13}, P$. parichhaii and P. pahujiir, P. laxmibail ${ }^{10}$, in having oval vitelline lobes, posterior-lateral to ventral sucker, right vitelline lobe is larger than left vitelline lobe, eggs are oval, non-operculated.

There fore it is consider as a new species with specific name $P$. betwaensis n.sp. after the collection of host from Betwa River, Bundelkhand region, district Jhansi. 


\section{ACKNOWLEDGEMENTS}

The author was thankful to principal \& Head of the Department of Zoology, Bipin Bihari
(P.G) College Jhansi, for providing lab facilities during the course of study. The author was also thankful to Dr. S. F. Siddiqui for her valuable aid and direction in preparation of the manuscript.

\section{REFERENCES}

1. Berenit Mendoza-Garfias and Gerardo Peroz-Ponce. De Leon. Phyllodistomum centopomisp. n. (Digenea: Gorgoderidae) a parasite of fat Snook, Centropomus paralldus (Osterichthyes: Centopomidae), in the Papaloapan River at Tlacotalpan, Veracruz State, Mexico. Zootaxa, 1056: 4351 (2005).

2. Brooks, D.R and M.A. Mayes: Phyllodistomum scrippsi sp. N. (Digenea: Gorgoderidae) and Neobeendenia girellae (Hargis, 1955) Yamaguti, 1963 (Monogenea: Capsalidae) from the Californi sheephead, Pimelometopn pulchurum (Ayres) (Pisces: Labridae). Journal of Parasitology. 61:407408 (1975).

3. Dyal, J: Trematode parasites of Indian fishes, part II, Ind. Jour. Helm, 3(1), 93-116 (1949).

4. Fischthal, J.H: A description of Phyllodistomum lysteri Miller, 1940 (Trematoda: Gorgoderidae), from common white sucker. The Jour. Praisit, 38,(1), 242244 (1952).

5. Gupta, S. P. On a new trematode Phyllodistomum singhiai $\mathrm{n}$. sp. of the family Gorgoderidae Looss, 1899, from the intestine of a freshwater fish Mastacembelus armatus (Lac.). Ind. J. Helminth., 3: 21-28 (1951b).

6. Jaclyn Helt, John Janovy, Jr., and John Ubelaker: Phyllodistomum funduli n. sp. (Trematoda:: Gorgoderidae) from Fundulus sciadicus cope from cedar creek in Western Nebraska. J. Parasitol. 89(2): 346-350 (2003).

7. Naz, S and S. F. Siddiqui: Two digenetic trematodes Phyllodistomum parichhaii and P. pahujii (Trematoda: Gorgoderidae, Looss, 1901), from fresh water fish Xenentodon cancila (Ham.) from different water bodies, district Jhansi Bundelkhand region.
International Journal of Innovation in Bioscience. 2(4), 229-231(2012).

8. Rai, S.L: Observation of the life history of Phyllodistomum srivastavai sp. $\mathrm{n}$. (Trematoda: Gorgoderidae). Journal of Parasitology, 54: 43-51 (1964).

9. Sarwat M. S: A new spoecies of genus Phyllodistomum (Braun, 1899), (Digenea: Gorgoderidae, Looss, 1901) from freshwater fish Mastacembelus armatus Aurangabad (M.S.) India. Recent Research in Science and Technology. 3(8): 11-13 (2011).

10. Sen Jag Mohan and S. F. Siddiqui: A new gorgoderid trematode of genus Phyllodistomum (Digenea: Gorgoderidae) a parasite of fresh water fish, Xenentodon cancila (BI.) from Matatila Reservoir, Jhansi, India. An International Research Journal of Biological Science "Flora and Fauna" 19(1): 158-160 (2013).

11. Suzana B Amato, J.F.R. Amato: A new species of Phyllodistomum Braun, 1899(Digenea: Gorgodridae) from Rhamdia quelen (Quoy and Gaimard, 1824) (Siluriformes: Pimelodidae). Mem.Inst. Oswaldo Cruz, Rib de Janeoro, 88(4): 557559 (1993).

12. Wen Xiang Li, Gui Tang Wang, Wei Jain Yoa and P. Nie: Phyllodistomum pavlovskii (Trmatoda: Gorgoderidae) in the bullhead catfish, Pseudobagrus fulvidraco, in the lake of China, Journal of Parasitology. 91(4): 850 853 (2005).

13. Zhokhov, A.Z, and A.E, Koxob: A new gorgoderid trematode of genus Phyllodistomum (Digenea: Gorgoderidae) from Clarius gariepinus (Actinopterygii: Claridae) in lake Tana, Ethiopia. Zoosystematica Rossica. 19(1): 9-12 (2010). 